
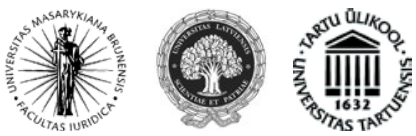

ISSN 1392-6195 (print) ISSN 2029-2058 (online) JURISPRUDENCIJA JURISPRUDENCE 2014, 21(3), p. 707-730.

\title{
EUROPOS SĄJUNGOS INSTITUCIJŲ TEISĖTAS IR NETEISĖTAS NEVEIKIMAS
}

\author{
Arvydas Budnikas \\ Mykolo Romerio universiteto Teisès fakulteto \\ Tarptautinès ir Europos Sąjungos teisès institutas \\ Ateities g. 20, LT-08303 Vilnius, Lietuva \\ Tel. +37064804729 \\ Elektroninis paštas: arvydas.budnikas@yahoo.com \\ Pateikta 2014 m. liepos 17 d., parengta spausdinti 2014 m. rugsèjo $18 \mathrm{~d}$. \\ doi:10.13165/JUR-14-21-3-04
}

\section{Ivadas}

Galimybė pateikti ieškinius dèl Europos Sąjungos (toliau tekste vadinama ir ES) institucijų neveikimo yra įtvirtinta Sutarties dèl Europos Sąjungos veikimo (toliau tekste vadinama ir SESV) 265 straipsnyje. Šis SESV straipsnis leidžia privatiems asmenims kreiptis ị ES Bendrąji Teismą, o ES institucijoms ir valstybėms narèms - i ES Teisingumo Teismą siekiant, kad būtų konstatuotas neteisètas ES institucijų neveikimas $^{1}$. Teisinejje literatūroje nèra atskleista, koks ES institucijų neveikimas gali

1 SESV 265 straipsnyje ittvirtinta: „Jei Europos Parlamentas, Europos Vadovu Taryba, Taryba, Komisija arba Europos centrinis bankas, pažeisdami Sutartis, nesiima atitinkamu veiksmu, valstybès narès ir kitos Sajungos institucijos gali kreiptis $j$ Europos Sajungos Teisingumo Teisma su ieškiniu dèl šio pažeidimo nustatymo. Šis straipsnis tokiomis pačiomis sq̨lygomis taikomas Sajungos įstaigoms ir organams, nesiimantiems veiksmų. Ieškinys priimamas tiktai tuo atveju, jeigu ta institucija, įstaiga ar organas buvo pirmiau paragintas imtis atitinkamu veiksmu. Jei per du menesius po tokio paraginimo ta institucija, ịstaiga ar organas neapibrèžia savo pozicijos, ieškinys gali büti pateikiamas per kitus du mènesius. Kiekvienas fizinis ar juridinis asmuo pirmesnèse pastraipose išdèstytomis sąlygomis gali paduoti Teismui skundą, kad Sajungos

Jurisprudencija/Jurisprudence

(C) Mykolo Romerio universitetas, 2014

(C) Mykolas Romeris University, 2014
ISSN 1392-6195 (print), ISSN 2029-2058 (online) http://www.mruni.eu/lt/mokslo_darbai/jurisprudencija/ http://www.mruni.eu/en/mokslo_darbai/jurisprudencija/ 
būti pripažĭstamas neteisètu. Ieškiniai dèl neveikimo lakoniškai ir nesistemiškai aptariami tik bendrojo pobūdžio ES teisès vadovèliuose ir ES teisès leidiniuose ${ }^{2}$. Svarbu akcentuoti, kad ES Bendrasis Teismas ${ }^{3}$ ir ES Teisingumo Teismas (toliau tekste kartu vadinami ES teismais) laikosi nuoseklios praktikos, kad daugeliu atvejų ES institucijos turi laisvę pasirinkti veikti ar neveikti (diskreciją), todèl jų neveikimas laikomas teisètu. Neveikimas pagal ES teismų praktiką neteisètu pripažįstamas tik esant piktnaudžiavimui siaura diskrecija arba esant pareigai veikti. Pastebima, kad ieškovai ES institucijų neveikimo sąvoką dažnai interpretuoja ịvairiai ir nežino, kokiais kriterijais vadovaujantis nustatoma, ar konkretus neveikimas yra teisètas, ar neteisètas. Pavyzdžiui, ES Komisija neturi pareigos pradèti procedūrą dèl pažeidimo prieš valstybę narę pagal SESV 258 straipsni, tačiau ieškovai ir po nepalankių ES teismų sprendimų toliau nuolat kreipiasi į ES teismus, siekdami, kad ES teismai pripažintų ES Komisijos neveikimą pagal SESV 258 straipsnį neteisètu ${ }^{4}$. Tokiu būdu, esant iš anksto aiškiai nepalankiai ieškovui bylos baigčiai, yra švaistomi tiek pačių ieškovų, tiek ir ES institucijų, kurios yra ịtraukiamos ị teisminị procesą kaip atsakovès ir turi ginti savo pagrịstas pozicijas neveikti, žmogiškieji ir finansiniai ištekliai.

Kai ieškovai nežino priežasčių, dèl kurių tam tikrais atvejais ES institucijų neveikimo neįmanoma pripažinti neteisètu, ir vis tiek siekia kvestionuoti ES teismų praktiką, jų ieškiniai siekiant pripažinti ES institucijų pagrịstą neveikimą neteisètu yra nesèkmingi. Todèl ieškovams gali kilti klausimų, ar yra galimybès ir kokios ap-

institucija arba įstaiga ar organas to asmens atžvilgiu neprieme kokio nors akto, išskyrus rekomendacija ar nuomonę."

2 Žr., pvz., Lenaerts, K.; Maselis, I.; Gutman, K. EU procedural law, Oxford University Press, 2014, p. 419-440; Craig, P.; de Búrca, G. EU Law. Text, cases and materials“, fifth edition, Oxford University press, 2011, p. 512-514; Schermers, G. H.; Waelbroeck, F. D. Judicial Protection in the European Union, 6th edition. Kluwer Law International, 2001, p. 463-484 ir kt.

3 ES Bendrasis Teismas iki $2009 \mathrm{~m}$. ịsigaliojusios Lisabonos sutarties buvo vadinamas Pirmosios instancijos teismu.

4 Nors ES teismai laikosi nuoseklios praktikos, ittvirtintos dar 1966 m. byloje Alfons Lütticke $\mathrm{GmbH}$ prieš ES Komisiją, kad neįmanoma ịpareigoti ES Komisijos pradèti pažeidimo procedūrą prieš valstybę narę pagal SESV 258 straipsnį, kadangi ES Komisija turi diskreciją šioje srityje, tačiau ieškovai vis tiek nuolat kreipiasi ị ES teismus su prašymu pripažinti ES Komisijos neveikimą pagal minètą straipsnị neteisètu. Žr., pvz., ES Teisingumo Teismo 2013 m. liepos 27 d. sprendimą byloje Alexandru Octavian Concal prieš ES Komisiją, bylos Nr. C-570/12P, Rink. nepaskelbta; 2013 m. liepos 27 d. sprendimą byloje Emil Micsunescu priě̌ ES Komisiją, bylos Nr. C-569/12 P, Rink. nepaskelbta; 2013 m. birželio 27 d. sprendimą byloje Doru Cristian Ioanovici prieš ES Komisiją, bylos Nr. C-568/12 P, Rink. nepaskelbta, Rink. p. II-01389; 1966 m. kovo 1 d. sprendimą byloje Alfons Lütticke GmbH prieš ES Komisiją, bylos Nr. 48/65, Rink. p. 00019; Bendrojo Teismo 2012 m. rugsèjo 25 d. sprendimą byloje Alexandru Octavian Concal prieš ES Komisiją, bylos Nr. T-320/12, Rink. nepaskelbta; 2012 m. rugsèjo 25 d. sprendimą byloje Emil Micsunescu prieš ES Komisiją, bylos Nr. T-314/12, Rink. nepaskelbta; 1994 m. gegužès 27 d. sprendimą byloje J prieš ES Komisiją, bylos Nr. T-5/94, Rink. p. II-00391, paras 15; 1994 m. liepos 4 d. sprendimą byloje Century Oils Hellas AE prieš ES Komisija, bylos Nr. T-13/94, Rink. p. II-00431 ir kt. 
skųsti atitinkamą ES institucijos neveikimą. Dèl anksčiau nurodytų priežasčių šio mokslinio straipsnio tikslas yra ne pati procedūros pagal SESV 265 straipsnị analizė, bet šiame moksliniame straipsnyje atskleidžiama, kokie požymiai lemia, kad ES institucijų neveikimas yra pripažịstamas teisètu arba neteisètu. Siekiant išvengti nepagrịstų ginčų ir siekiant taupyti ES institucijų resursus bei padėti ieškovams suprasti, koki neveikimą galima ir verta skųsti, reikètų atskleisti, koks ES institucijų neveikimas yra teisètas ir koks ES institucijų neveikimas yra neteisètas. Pažymėtina, kad tik neteisèto neveikimo atveju procesas pagal SESV 265 straipsnị prieš ES instituciją ieškovui gali būti sèkmingas.

Moksliniame straipsnyje taikomi loginis-analitinis, sisteminès analizès, lingvistinis, apibendrinimo ir išvadų metodai.

\section{ES institucijų neveikimo samprata}

SESV 265(1) straipsnyje yra itvirtinta, kad „Jei Europos Parlamentas, Europos Vadovu Taryba, Taryba, Komisija arba Europos centrinis bankas, pažeisdami Sutartis, nesiima atitinkamu veiksmu, valstybès narès ir kitos Sajungos institucijos gali kreiptis i Europos Sajungos Teisingumo Teisma su ieškiniu dèl šio pažeidimo nustatymo“. Nei ES sutartyse, nei kituose ES teisès aktuose nèra nurodyta, ką reiškia „nesièmimas atitinkamų veiksmų“, t. y. „neveikimas“. Atsižvelgiant ị tai ši sąvoka yra plètota ES teismų praktikoje ir teisès doktrinoje.

Generalinis advokatas Capotorti Gema byloje yra nurodęs, kad ES teisèje sąvoka ES institucijų „veikimas“ (angl. action) reiškia teisès akto prièmimą, o sąvoka ES institucijų „neveikimas“ (angl. inaction) reiškia teisès akto neprièmimą. Kai ES institucija tam tikru klausimu nepriima teisès akto (neveikia), toki jos neveikimą galima skųsti pagal SESV 265 straipsni $i^{5}$. Generalinis advokatas Dutheillet nurode, kad ieškinị dèl neveikimo pagal SESV 265 straipsnị galima pateikti tik tuo atveju, jeigu nèra tuo klausimu apskritai priimtas joks teisès aktas, o jeigu yra priimtas teisès aktas veiksmų nesiimti, ieškinys dèl neveikimo pagal SESV 265 straipsnị negalimas, nes institucija veikè, t. y. prièmé teisès aktą veiksmų nesiimti. ${ }^{6}$ Toks požiūris vyrauja ir ES teismų praktikoje ${ }^{7}$.

5 Generalinio advokato Capotorti 1979 m. liepos 11 d. išvada byloje GEMA prieš ES Komisija, bylos Nr. 125/78, Rink. p. 03173, para 5.

6 Generalinio advokato Dutheillet $1971 \mathrm{~m}$. rugsèjo 28 d. išvada byloje Mackprang prieš ES Komisija, bylos Nr. 15/71, Rink. p. 00797, p. 808; taip pat žr., pvz., ES Teisingumo Teismo $1971 \mathrm{~m}$. liepos 13 d. sprendimą byloje Deutscher Komponistenverband prieš ES Komisiją, bylos Nr. 8/71, Rink. nepaskelbta.

7 ES Teisingumo Teismo 2013 m. gegužès 16 d. sprendimas byloje ES Komisija prieš Ryanair Ltd, bylos Nr. C-615/11 P, Rink. nepaskelbta. para 39; $1993 \mathrm{~m}$. vasario $16 \mathrm{~d}$. sprendimas byloje Empresa Nacional de Urânio SA prieš ES Komisija, bylos Nr. C-107/91, Rink. p. I-00599, para 10 p.; ES Teisingumo Teismo 1985 m. gegužès 22 d. sprendimas byloje Europos Parlamentas prieš ES Tarybą, bylos Nr. 13/83, Rink. p. 01513, p. 1567; ES Bendrojo Teismo 2013 m. rugsejo 
Kaip matyti, ES teismai ir kai kurie teisès mokslininkai ${ }^{8}$ ES institucijos neveikimą traktuoja tik kaip atsisakymą priimti teisès aktą, o veikimu laiko teisès akto prièmimą. Vadovaujantis tokiu požiūriu, nèra svarbu, kad ES institucija priima teisès aktą, kuriuo jokių veiksmų neatlieka, užtenka vien paties fakto, kad teisès aktas priimtas ir tai jau laikoma veikimu. Taigi, pagal tokią tradicinę neveikimo sampratą SESV 265 straipsnyje įtvirtintas „, $<. .>$ nesiemimas atitinkamu veiksmų <...> " reiškia tik teisès akto atitinkamu klausimu neprièmimą. Pažymėtina, kad aiškinant neveikimą tik kaip teisès akto neprièmimą, praktiškai gali išnykti riba tarp veikimo ir neveikimo, jeigu bus žiūrima ị rezultatą. Pavyzdžiui, ieškovas siekia, kad ES institucija atliktų konkrečius veiksmus. Jeigu ES institucija nepriima teisès akto tuos veiksmus atlikti, kaip minèta, tai yra laikoma neveikimu. Tačiau jeigu ES institucija priimtų teisès aktą tų veiksmų neatlikti, tai jau būtų laikoma veikimu. Nepaisant to, kad vienu atveju tai būtų laikoma neveikimu, o kitu atveju veikimu, tiek veikimo, tiek neveikimo rezultatas išlieka tas pats, kadangi aktyvūs veiksmai neatliekami. Dèl šios rezultato problematikos, teisès doktrinoje vystoma alternatyvi neveikimo samprata, kuri yra analizuojama toliau.

Taigi, galimas ir alternatyvus „neveikimo“ aiškinimas, atskiriant turinị ir formą, t. y. veiksmų nesiẻmimą (neveikimą) ir veiksmų nesiẻmimo ịforminimą (teisès aktą). Kaip nurodo mokslininkas T. C. Hartley, negatyvus teisès aktas, kuriuo ES institucija atsisako imtis veiksmų, taip pat savo esme yra neveikimas, tik prieš tokị neveikimą ginamasi ne ieškiniu dèl neveikimo pagal SESV 265 straipsnị, bet ieškiniu dèl teisès akto panaikinimo pagal SESV 263 straipsnị. Kaip matyti, T. C. Hartley tokị požiūrị argumentuoja tuo, kad negatyviu sprendimu vis vien yra neveikiama, t. y. atsisakoma atlikti pozityvius veiksmus, nepaisant to, kad tokio atsisakymo forma yra negatyvus teisès aktas, o ne ES institucijos tyla, kaip kad SESV 265 straipsnio atveju

Galima įžvelgti, kad remiantis tokiu alternatyviu požiūriu, ES institucijos veikimas galètų būti suprantamas kaip teisès akto prièmimas, kuriuo nusprendžiama imtis aktyvių veiksmų, pavyzdžiui, sprendimo prièmimas konstatuoti konkurencijos teisès pažeidimą. Tuomet neveikimas, priešingai, galètų būti aiškinamas kaip (i) jokio sprendimo neprièmimas ir toks neveikimas yra ginčijamas pagal SESV 265 straipsni, arba (ii) negatyvaus sprendimo priemimas, kuriuo atsisakoma atlikti aktyvius veiksmus ir toks neveikimas ginčijamas pagal SESV 263 straipsnị. Pavyzdžiui, neveikimo atvejis, kai ES Komisija raštišku sprendimu netirtų konkurencijos teisès pažeidimo, būtų ginčijamas pagal SESV 263 straipsnị.

26 d. sprendimas byloje Pioneer Hi-Bred International prieš ES Komisija, bylos Nr. T-164/10, Rink. nepaskelbta, para 71; 2011 m. rugsejo 29 d. sprendimas byloje Ryanair prieš Komisiją, bylos Nr. T-442/07. Rink. p. II-00333 para 78 ir kt.

8 Žr., pvz., Lenaerts, K.; Maselis, I.; Gutman, K. EU procedural law, Oxford University Press, 2014, p. 421, Steiner, J.; Woods, L.; Watson, P. EU law, 11th edition, Oxford University Press, 2012, p. 293 ir kt.

9 Hartley, T. The foundations of European Union law, $8^{\text {th }}$ edition, Oxford University Press, 2014, p. 350, Hartley, T. the foundations of the European Community law, $6^{\text {th }}$ edition, Oxford University Press, 2007, p. 372-373. 
Gali kilti klausimas, ar pagal SESV 265 straipsnị leistina ginčyti priimtus aktus nesiimti veiksmų? Pažymėtina, kad ES teismų praktika klausimu, ar pagal SESV 265 straipsni galima ginčyti teisès aktą nesiimti veiksmų, yra paini. Byloje Europos Parlamentas prieš ES Tarybą, ES Teisingumo Teismas pažymèjo, jog dèl to, kad ES Taryba nepateikẻ biudžeto projekto, Europos Parlamentas galèjo pareikšti ieškinị dèl neveikimo ir toliau nurodè, jog „<...> dèl atsisakymo imtis veiksmu, kad ir koks jis tiesioginis, galima kreiptis $i$ Teisingumo Teisma remiantis SESV 265 straipsniu, jei neveikimas nenutraukiamas" ${ }^{\text {"10 }}$. Ar ES Teisingumo Teismas šiuo teiginiu norèjo konstatuoti, kad pagal SESV 265 straipsnị galima ginčyti tiesioginị atsisakymą veikti, t. y. atsisakymą veikti priimtu teisès aktu? Nepaisant tokios iš esmès revoliucinès minties, šis ES Teisingumo Teismo teiginys taip ir nebuvo paaiškintas bei detaliau išplètotas, todèl teisès doktrinoje buvo pavadintas „paslaptinguoju“11. Nepaisant šio mịslingo teiginio, ES Teisingumo Teismas praktikoje paprastai laikosi pozicijos, kad ieškinys dèl neveikimo pagal SESV 265 straipsnị nepriimtinas, jeigu yra tuo klausimu priimtas negatyvus teisès aktas, kuriuo atsisakoma imtis veiksmų ${ }^{12}$. Tačiau minètas teiginys byloje Europos Parlamentas prieš ES Taryba parodè, kad net ir ES Teisingumo Teismas savo praktikoje pripažino, kad „neveikimo“ sąvoką tapatinti tik su teisès akto neprièmimu yra ne- visiškai tikslu ir pakankama.

Apibendrinant visą anksčiau nurodytą problematiką, galima padaryti atitinkamas išvadas. ES institucijų „neveikimas“ tradiciškai, t. y. išimtinai SESV 265 straipsnio prasme, turètų būti suprantamas tik kaip visiškas neveikimas, kai ES institucija ne tik kad nesiima veiksmų, bet ir nepriima teisès akto, kuriuo įformintų savo atsisakymą veiksmų nesiimti. Tuo tarpu ES institucijų „neveikimas“ alternatyviu aspektu reiškia ES institucijų veiksmų nesiemimą bet kokia forma, nesvarbu, ar veiksmai neatliekami tylejimu (nepriimamas teisès aktas), ar veiksmai neatliekami ekspresyviai (priimamas negatyvus teisès aktas). Pastaruoju atveju ES institucijų neveikimas nèra siejamas išimtinai tik su ieškinių dèl neveikimo procedūra pagal SESV 265 straipsnị, kadangi SESV 265 straipsnis nesuteikia galių prašyti teismo panaikinti teisès aktą ${ }^{13}$. Teisès aktu įformintas veiksmų nesièmimas yra ginčijamas ieškiniu dèl panaikinimo pagal SESV 263 straipsni $^{14}$.

10 ES Teisingumo Teismo 1988 m. rugsèjo 27 d. sprendimas byloje Europos Parlamentas prieš ES Tarybą, bylos Nr. 302/87, Rink. p. 05615, para 17.

11 Simon, D. „Le système juridique communautaire“, $2^{\text {nd }}$ edition, Presses Universitaires de France, Paris, 1998, Nr. 379, p. 402.

12 Žr., pvz., ES Teisingumo Teismo $2010 \mathrm{~m}$. lapkričio 18 d. sprendimą byloje NDSHT prieš ES Komisija, bylos Nr. C-322/09 P, Rink. p. I-11911, para 53-54.

13 Kaip minèta anksčiau, jeigu pagal SESV 265 straipsnị būtų galima panaikinti sprendimus, SESV 263 straipsnio procedūra netektų prasmès, nes būtent ji yra skirta ES intitucijų sprendimų panaikinimui, o ne SESV 265 straipsnis.

14 Šiame straipsnyje pagrindinis dèmesys yra skiriamas tradicinès neveikimo sampratos analizei, o alternatyvi neveikimo samprata analizuojama tik tiek, kiek reikalinga visapusiškai ir detaliai atskleisti tradicinès neveikimo sampratos trūkumus asmens teisių gynybai. 
Toliau yra analizuojama, koks ES institucijų neveikimas pagal SESV 265 straipsnị gali būti pripažintas teisètu, t. y. nepaisant to, kad ES institucija nepriimtų teisès akto imtis aktyvių veiksmų, vis tiek būtų pripažinta, kad toks neveikimas yra teisètas ${ }^{15}$.

\section{Teisètas neveikimas esant plačiai diskrecijai neveikti}

Svarbu nustatyti, kokiais kriterijais vadovaujantis yra sprendžiama, kad ES institucijos neveikimas yra teisètas. Dar neteismine tvarka nustačius, kad neveikimas yra teisètas, nebūtų pagrindo kvestionuoti ES institucijos neveikimo ir reikšti nepagrịstus reikalavimus, kuriais būtų siekiama pripažinti neveikimą neteisètu. Ar ES institucijos neveikimas yra teisètas, priklauso nuo ES institucijos turimos diskrecijos teisès, tačiau teisinèje literatūroje dažniausiai diskrecija siejama su ES institucijų veikimu.

Generalinis advokatas Léger bylos Rica Foods išvadoje nurodè, kad galima skirti dvi ES institucijų diskrecijos kategorijas, kai ES institucijos veikia ${ }^{16}$. Minèto generalinio advokato teigimu, „politinio“ pobūdžio diskrecija reiškia galimybę priimti politinio pobūdžio sprendimus, skirtus neapibrèžtai asmenų grupei ${ }^{17}$, o kita, „techninio“ pobūdžio diskrecija yra individualių sprendimų, visų pirma, konkurencijos teisès srityje, priemimas ${ }^{18}$. Pripažinimas, kad pagal atitinkamą ES teisès normą ES institucija turi diskreciją, reiškia teisminès kontrolès ES institucijai apribojimą ir ES institucijos veikimo pasirinkimo laisvę. Pažymėtina, kad apskundus ES institucijos, turinčios diskreciją, veiksmus, teismas turi patikrinti tik tai, ar buvo laikomasi procedūrinių ir naudojimosi diskrecija motyvavimo taisyklių, ar faktai, kuriais grindžiamas atitinkamas sprendimas, atitinka tikrovę, ar nèra akivaizdžių vertinimo klaidų priimant vienokio ar kitokio pobūdžio teisès aktą ${ }^{19}$.

ES institucijų turimos diskrecijos reikšmė vertinant ES institucijų veikimo teisètumą yra plačiai išanalizuota ${ }^{20}$, tačiau teisinejje literatūroje beveik neaptariama, ko-

15 Šiame straipsnyje pagrindinis dėmesys yra skiriamas tradicinei neveikimo sampratai, t. y. neveikimą siejant išimtinai tik su SESV 265 straipsniu, o neveikimas su SESV 263 siejamas tik tiek, kiek SESV 265 straipsnis yra nepakankamas siekiant ginčyti priimti sprendimą nesiimti veiksmų.

16 Generalinio advokato Léger $2005 \mathrm{~m}$. vasario $17 \mathrm{~d}$. išvada byloje Rica Foods (Free Zone) NV priěs ES Komisija, C-40-03, Rink. p. I-6811, para 45.

17 Šiame kontekste taip pat žr. ES Teisingumo Teismo $1990 \mathrm{~m}$. vasario $21 \mathrm{~d}$. sprendimą sujungtose bylose Wuidart ir kt., bylų Nr. C-267/88 ir C-285/88, Rink. p. I-435, para 14; 1990 m. birželio 26 d. sprendimas byloje Zardi, bylos Nr. C-8/89, Rink. p. I-2515, para 11; Bendrojo teismo 1996 m. birželio 5 d. sprendimas NMB Prancūzija ir kt. prieš Komisiją, bylos Nr. T-162/94, Rink. p. II-427, para 70.

18 Generalinio advokato Léger 2005 m. vasario 17 d. išvada byloje Rica Foods (Free Zone) NV prieš ES Komisija, C-40-03, Rink. p. I-6811, paras 46-47.

19 Ibid., para 47.

20 Žr., pvz., Fritzsche, A. Discretion, scope of judicial review and institutional balance in European Union. Common Market Law Review. 2010, Vol. 47, Iss. 2: 361-403; Galligan, D. J. Discretionary powers, a legal study of official discretion. Oxford: Clarendon Press, 1986 ir kt. 
kią reikšmę diskrecija turi ES institucijų neveikimui ir jo teisètumo vertinimui. Anot profesoriaus E. Biberio, svarbiausia neveikimo atveju yra nustatyti, ar ES institucija tinkamai pasielgè nuspręsdama neveikti, kitaip tariant, ar ES institucija tinkamai igyvendino savo diskrecijos teisę neveikti, užuot pasirinkusi veikimą ${ }^{21}$. Kaip matyti iš ES teismų praktikos, ES institucijų neveikimo kontekste plati diskrecija ES institucijai suteikia teisę nepriimti sprendimo arba priimti sprendimą, kuriuo ES institucija konstatuos, kad atitinkamu klausimu neveiks ${ }^{22}$. Jeigu ES institucija neveiks ir, kilus dèl to ginčui, teismo bus pripažinta, kad ji turèjo plačią diskrecijos teisę, tokiu atveju ES institucijos neveikimas bus pripažintas teisètu. Svarbu nustatyti kriterijus, pagal kuriuos būtų galima vertinti, ar ES institucija turi plačią diskrecijos teisę neveikti, ar jos neturi. Kaip minèta, toks ịvertinimas reikalingas tam, kad ieškovai, dar prieš kreipdamiesi ị teismą, galètų preliminariai žinoti, ar yra perspektyvos pripažinti ES institucijos neveikimą neteisètu ir nepagrịstai nekaltintų ES institucijų neveikimu.

ES Bendrasis Teismas byloje Rendo konstatavo, kad lingvistinis nuostatų išaiškinimas paprastai identifikuoja ES institucijos plačią diskreciją veikti ar neveikti ${ }^{23}$. Kaip matyti iš ES Teisingumo Teismo sprendimo byloje Dow, plati diskrecijos teisè konkrečioje ES teisès normoje dažniausiai apibūdinama žodžiu "gali“ (angl. may) ir tokioje teisès normoje nèra numatyta sąlygų, kada ES institucija turètų diskreciją realizuoti, t. y. veikti ${ }^{24}$. Jeigu ES institucija pagal ES teisès normą „gali“ imtis veiksmų, o ne „privalo“ jų imtis bei nèra numatyta sąlygų, kurioms esant ES institucija veiksmus atlikti privalo, tai reiškia, kad ji turi plačią diskreciją tų veiksmų nesiimti. Taigi, ES institucijų plačiai diskrecijos teisei nustatyti paprastai yra taikomas lingvistinis teisès normos aiškinimo metodas. Tokią išvadą patvirtina ir nusistovejjusi ES Teisingumo Teismo praktika, kuri teigia, kad vertinant ir interpretuojant ES teisès normą, reikia atsižvelgti i jos formuluotę, vartojamus žodžius, kontekstą ir tikslus ${ }^{25}$. Papildomai pa-

21 Biber, E. Two Sides of the Same Coin: Judicial Review of Administrative Agency Action and Inaction. Virginia Environmental Law Journal. 2008. Vol. 26, No. 3: 461-463.

Žr., pvz., ES Bendrojo Teismo $2011 \mathrm{~m}$. rugsèjo 6 d. sprendimą byloje Muhamad Mugraby prieš ES Taryba ir ES Komisija, bylos Nr. T-292/09, paras 39-44, 60; Rink. nepaskelbta, 1997 m. liepos 10 d. sprendimą byloje Nr. T-81/96 Christos Apostolidis ir kt. prieš ES Komisiją, bylos Nr. T-81/96, Rink. p. FP-II-00607, paras 10-12.

23 ES Bendrojo Teismo $1992 \mathrm{~m}$. lapkričio $11 \mathrm{~d}$. sprendimas byloje Rendo NV, Centraal Overijsselse Nutsbedrijven NV and Regionaal Energiebedrijf Salland NV prieš ES Komisiją, bylos Nr. T-16/91, Rink. p. II-02417, paras 96 - 101.

24 ES Teisingumo Teismo 2013 m. liepos 18 d. sprendimas Dow, bylos Nr. C-499/11 P, Rink. nepaskelbta, paras 43-44.

25 Žr., pvz., ES Teisingumo Teismo 1984 m. vasario 21 d. sprendimą byloje St. Nikolaus Brennerei und Likörfabrik, Gustav Kniepf-Melde GmbH prieš Hauptzollamt Krefeld, bylos Nr. 337/82, Rink. p. 01051, para 10; 1996 m. liepos 30 d. sprendimą byloje Bosphorus Hava Yollari Turizm ve Ticaret AS prieš Minister for Transport, Energy and Communications ir kt., bylos Nr. C-84/95, Rink. p. I-03953, para 11, ES Teisingumo Teismo 1999 m. lapkričio 18 d. sprendimą Pharos SA prieš Europos Bendrijų Komisiją, bylos Nr. C-151/98 P, Rink. p. I-08157 para 19 ir kt. 
žymėtina, kad ES Bendrasis Teismas byloje Yusef konstatavo, kad ES institucija plačią diskrecijos teisę veikti ar neveikti turi ir tuo atveju, jeigu apskritai nèra teisės normos, kuri ES instituciją ịpareigotų tuo klausimu veikti ${ }^{26}$. Toliau yra analizuojami aktualūs atvejai, kai ieškovai siekia pripažinti ES institucijos neveikimą neteisètu, nepaisant to, kad neveikimas visuomet laikomas teisètu ir ieškovo reikalavimai yra netenkinami.

Pavyzdžiui, SESV 258 straipsnyje yra įtvirtinta, kad „Jei Komisija mano, kad kuri nors valstybè narè neįvykdè kokios nors pareigos pagal Sutartis, ji šiuo reikalu pareiškia pagrista savo nuomonę, pirma suteikusi atitinkamai valstybei narei galimybę išdestyti savo pastabas. Jei atitinkama valstybe naré per Komisijos nustatytą laiką neatsižvelgia ị tą nuomonę, Komisija gali perduoti ši reikala svarstyti Europos Sajungos Teisingumo Teismui“. Pažymėtina, kad pagal minèto SESV 258 straipsnio normas ES Komisija turi plačią diskreciją pradèti pažeidimo procedūrą prieš valstybę narę. Nagrinėdamas klausimą dèl ES Komisijos ịpareigojimo tirti valstybių narių pažeidimus, ES Teisingumo Teismas garsiojoje Star Fruit byloje nurodè, kad ES Komisija pagal SESV 258 straipsnị turi plačią diskreciją pasirinkti: tirti ar netirti pažeidimų, kuriuos galimai padaro valstybės narès. ES Teisingumo Teismas konstatavo, kad ši plati diskrecija yra akivaizdi skaitant pačios SESV 258 straipsnį, kuris suteikia tik kompetenciją, tačiau neipareigoja veikti, kadangi SESV 258 straipsnyje kalbama apie ES Komisijos galejjimą pradèti pažeidimo procedūrą, bet ne apie pareigą ${ }^{27}$. ES Teisingumo Teismas kitoje byloje Dumez nurodè, kad ES Komisija nèra ịpareigojama veikti pagal SESV 258 straipsnį net ir tais atvejais, kai keliamas rimtas galimo ES teisès pažeidimo klausimas, arba jeigu net nèra nacionalinių veiksmingų teisinės apsaugos priemonių konstatuoti pažeidimą ir ji pašalinti ${ }^{28}$. Kitos ES Bendrojo Teismo nagrinètos bylos: Concilia, Tiber, MAG yra svarbios tuo, kad ieškovai šiose bylose teige, kad ES Taryba turi bendro pobūdžio pareigą skatinti ES Komisiją pradèti pažeidimo procedūrą prieš valstybę narę. ES Bendrasis Teismas minètose bylose konstatavo, kad SESV 258 straipsnis ES Tarybai apskritai nesuteikia jokių igaliojimų skatinti ES Komisiją pradėti pažeidimo procedūrą prieš valstybę narę, todèl ES Taryba neturi minètos pareigos, jeigu ES Komisija atsisako pradèti pažeidimo procedūrą ${ }^{29}$. Atkreiptinas dèmesys ir ị tai, kad net

26 ES Bendrojo Teismo 2014 m. kovo 21 d. sprendimas byloje Hani El Sayyed Elsebai Yusef priě̌ ES Komisija, bylos T-306/10, Rink. nepaskelbta, para 107.

27 ES Teisingumo Teismo 1989 m. vasario 14 d. sprendimas byloje Star Fruit Company SA priě̌ ES Komisija, bylos Nr. 247/87, Rink. p. 00291, para 11.

28 ES Teisingumo Teismo 1995 m. lapkričio 13 d. sprendimas byloje Dumez prieš ES Komisija, bylos Nr. T-126/95, Rink. p. II-02863, para 38.

29 Žr. ES Bendrojo Teismo 2013 m. gruodžio 5 d. nutartị byloje MeD Concilia Srl prieš ES Taryba ir ES Komisija, bylos Nr. T-574/13, Rink. nepaskelbta, para 8; 2013 m. gruodžio 5 d. nutarti byloje Adr Tiber Srl prieš ES Taryba ir ES Komisija, bylos Nr. T-573/13, Rink. nepaskelbta, para 8; 2013 m. gruodžio 5 d. nutartị byloje MAG Dispute Resolution Srl prieš ES Tarybą ir ES Komisija, bylos Nr. T-572/13, Rink. nepaskelbta, para 8; taip pat žr. 2013 m. lapkričio 28 d. sprendimą byloje ADR Conciliando e ADR CઐM Consulting Srl prieš ES Tarybą ir ES Komisiją, bylos Nr. T-475/13, Rink. nepaskelbta.; $2013 \mathrm{~m}$. lapkričio $28 \mathrm{~d}$. sprendimas byloje ADUGI Onlus prieš ES Tarybą ir ES Komisiją, bylos Nr. T-474/13, Rink. nepaskelbta. 
tada, kai ES Komisija pagal pateiktą skundą ir nusprendžia tirti galimą pažeidimą, ES Komisija neturi pareigos informuoti apie tai ieškovą ir jị išklausyti ${ }^{30}$. Apibendrinant galima teigti, kad jeigu ES Komisija nesiima veiksmų pagal SESV 258 straipsni, tai ieškovui neverta inicijuoti procedūrą dèl ES Komisijos neveikimo, kadangi, bet kuriuo atveju ES Komisijos neveikimas būtu pripažintas teisètu dèl egzistuojančios plačios diskrecijos teisės šioje srityje. Dèl egzistuojančios plačios diskrecijos teisès ES Komisija nebus ịpareigota realizuoti diskreciją pagal SESV 258 straipsnį ir priimti sprendimą, kuriuo konstatuotų, kad valstybè narè pažeidžia ES teisès reikalavimus.

Kaip matyti iš ES Bendrojo Teismo sprendimo Apostolidis byloje, jeigu ES Komisija neinicijuoja proceso dèl kitos ES institucijos neveikimo pagal SESV 265 straipsnit, toks ES Komisijos neveikimas yra teisètas. Šis neveikimas pripažistamas pateisinamu būtent dèl egzistuojančios plačios diskrecijos teisès nesiimti veiksmų, nes SESV 265 straipsnis nenumato sąlygų, kurioms esant ES Komisija privalètų pareikšti ieškinį dèl kitos ES institucijos neveikimo ${ }^{31}$. ES Teisingumo Teismas, apeliacine tvarka išnagrinèjęs bylą Apostolidis, padare išvadą, kad ES Bendrojo Teismo sprendimas yra pagrịstas $^{32}$. Analizuojant SESV 265 straipsnị matyti, kad ES institucijos šioje srityje turi plačią diskrecijos teisę. SESV 265 straipsnis ịtvirtina, kad „Jei Europos Parlamentas, Europos Vadovu Taryba, Taryba, Komisija arba Europos Centrinis Bankas, pažeisdami Sutartis, nesiima atitinkamu veiksmu, valstybés narès ir kitos Sajungos institucijos gali kreiptis ị Europos Sąungos Teisingumo Teisma su ieškiniu dèl šio pažeidimo nustatymo <...> “. Lingvistiškai aiškinant SESV 265 straipsnị matoma, kad ES institucija negali būti ịpareigota pateikti ieškinị dèl neveikimo, jeigu ji to padaryti neketina, kadangi ji „gali“ kreiptis ị teismą dèl kitos ES institucijos neveikimo, tačiau taip pasielgti „neprivalo“. Be to, ši teisés norma nepateikia jokių sąlygų, kurioms esant ES Komisija privalètų veikti. Apibendrinant galima padaryti išvadą, kad jeigu ieškovas pageidautų, kad ES institucija inicijuotų bylą dèl neveikimo pagal SESV 265 straipsnị prieš kitą ES instituciją, tačiau ES institucija tokio prašymo nevykdytų, tai ieškovui nevertètu inicijuoti proceso dèl neveikimo prieš ieškovo prašymo nevykdančią ES instituciją. Tokia išvada gaunama dèl to, kad neveikimas, dèl egzistuojančios plačios diskrecijos teisès, negalètų būti pripažintas neteisètu ir ieškovas negalètų siekti, kad ES institucija būtų ịpareigota pareikšti ieškinị dèl neveikimo.

Be kitu igaliojimų, ES Komisija turi plačią diskreciją nustatyti draudžiamų susitarimų ir piktnaudžiavimo dominuojančia padètimi pažeidimus. Igaliojimą ES Komisijai veikti ir nustatyti pažeidimus pagal SESV 101 ir 102 straipsnių normas

30 ES Bendrojo Teismo 1997 m. rugsejo 29 d. sprendimas byloje Société Anonyme de Traverses en Béton Armé (Sateba), bylos Nr. T-83/97, Rink. p. II-01523, para 32.

31 ES BendrojoTeismo $1997 \mathrm{~m}$. liepos 10 d. sprendimas byloje Nr. T-81/96 Christos Apostolidis ir kt. prieš ES Komisiją, bylos Nr. T-81/96, Rink. p. FP-II-00607, paras 10-12.

32 ES Teisingumo Teismo 1999 m. spalio 5 d. sprendimas Christos Apostolidis ir kt. prieš ES Komisija, bylos Nr. C-327/97 P, Rink. p. I-06709, paras 9-27. 
numato 2002 m. gruodžio 16 d. ES Tarybos reglamentas Nr. 1/2003. Šio reglamento 7 straipsnyje itvirtinta, kad „Kai Komisija, veikdama skundo pagrindu ar savo iniciatyva, nustato Sutarties 101 straipsnio ar 102 straipsnio pažeidima, ji gali priimti sprendima, reikalaujanti, kad įmonès ar įmoniu asociacijos nutrauktu pažeidima

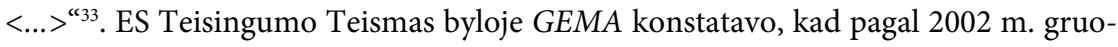
džio 16 d. ES Tarybos reglamento Nr. 1/2003 7 straipsnio nuostatas yra akivaizdu, kad ES Komisija neturi pareigos, o turi tik plačią diskrecijos teisę priimti sprendimą

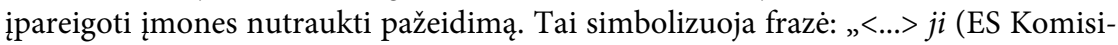
ja - aut. pastaba) gali priimti sprendima <...>“. Kitoje byloje Automec ES Bendrasis Teismas konstatavo, kad ES Komisijos negalima ịpareigoti atlikti antikonkurencinio elgesio rinkoje tyrimą ir negalima pripažinti ES Komisijos neveikimo neteisètu, nes ịpareigojimas būtų beprasmis: net ir atlikusi tyrimą, ES Komisija vis tiek gali nesiimti tolesnių veiksmų pažeidimui konstatuoti bei jị nutraukti dèl to, kad ES Komisija turi plačią diskreciją šioje srityje veikti, bet neturi pareigos veikti ${ }^{34}$. Taigi, galime daryti išvadą, kad tuo atveju, jeigu ES Komisija netiria galimo konkurencijos teisès pažeidimo pagal SESV 101 ir 102 straipsnius bei nepriima galutinio teisės akto, kuriuo tokius pažeidimus konstatuotų, ieškovas negalètų pripažinti tokị ES neveikimą pagal SESV 265 straipsnị neteisètu, kadangi ES Komisija turi plačią diskreciją tokius pažeidimus tirti ir konstatuoti.

ES Komisija turi ir plačią diskreciją valstybės pagalbos srityje. Valstybės pagalba reiškia bet kokią nacionalinių valdžios institucijų teikiamą paramą ūkio subjektams, kuri suteikia jiems konkurencinį pranašumą prieš kitus konkurentus ir neteisèta pripažistama tuomet, kai iškraipo ar gali iškraipyti konkurenciją rinkoje ${ }^{35}$. Svarbu atkreipti dèmesị ị tai, kad ES Komisija, net jeigu ji nustato neteisètai teikiamos valstybès pagalbos faktą ir priima dèl to sprendimą, kuriuo pagalbą uždraudžia, neprivalo kreiptis į ES Teisingumo Teismą pagal SESV 108(2) straipsnį, kad užtikrintų tokio sprendimo vykdymą. Byloje Aitec ES Komisija prièmé sprendimą Graikijai, kuriuo konstatavo, kad Graikija neteisètai teikia valstybės pagalbą ir sprendimu nurodė Graikijai pažeidimą pašalinti. ES Komisija nesièmė jokių veiksmų užtikrinti savo sprendimo ịvykdymą ir nesikreipe į ES Teisingumo Teismą bei laukè, kol pati Graikija sprendimą iggyvendins, t. y. pašalins pažeidimą. Graikija pažeidimo nepašalino, todèl ieškovas prašè ES Komisijos kreiptis ị teismą ir užtikrinti sprendimo ịvykdymą. ES Komisija ir toliau ị ES Teisingumo Teismą nesikreipe, todèl ieškovas siekẻ tokị ES

33 Pagal SESV 101 straipsnį draudžiama sudaryti verslo subjektams susitarimus, kurie iškreiptų ES vidaus rinkos veikimą, o SESV 102 straipsnis draudžia verslo subjektui piktnaudžiauti dominuojančia padètimi.

34 Ibid., paras 52, 54, 72

35 Valstybès pagalbos sąvoka yra išaiškinta SESV 107(1) straipsnyje, pagal kurị „Valstybès narès arba ǐ jos valstybiniu ištekliu bet kokia forma suteikta pagalba, kuri, palaikydama tam tikras i̇mones arba tam tikru prekiu gamybą, iškraipo konkurencija arba gali ja iškraipyti, yra nesuderinama su vidaus rinka, kai ji daro įtaka valstybiu nariu tarpusavio prekybai“. 
Komisijos neveikimą pripažinti neteisètu. ES Bendrasis Teismas Aitec byloje konstatavo, kad ES Komisija naudojasi plačia diskrecijos teise pagal SESV 108(2) straipsni spręsdama kreiptis ar nesikreipti į ES Teisingumo Teismą tuo atveju, jeigu valstybė narė nesilaiko ES Komisijos sprendime numatytų ịpareigojimų dẻl valstybės pagalbos draudžiamumo. Kaip nurode ES Bendrasis Teismas, ši ES Komisijos teise yra akivaizdi iš SESV 108(2) straipsnio turinio ir frazės „<...> (ES Komisija - aut. pastaba) gali ši klausima perduoti tiesiogiai Europos Sajungos Teisingumo Teismui", tačiau „neprivalo“ kreiptis ị ES Teisingumo Teismą ${ }^{36}$. Manytina, kad ES Komisijai prièmus sprendimą uždrausti teikti pagalbą ir valstybei narei jo nevykdant, ES Komisija privalètų imtis visų atitinkamų priemonių sprendimo laikymosi užtikrinimui. Priešingu atveju, neteisètai teikiamos valstybès pagalbos konstatavimas neturètų jokios prasmès ir valstybei pažeidèjai nesukeltų jokių pasekmių, kadangi konkurencijos teisès pažeidimas būtų ir toliau leidžiamas. Manytina, kad negali būti toleruojama situacija, kai valstybei narei leidžiama nevykdyti ES institucijų priimtų sprendimų, tačiau ieškovai negalètų pripažinti ES Komisijos neveikimo neteisètu, jeigu ES Komisija nesiimtų veiksmų užtikrinti sprendimo, priimto valstybės pagalbos srityje, igyvendinimą.

Pažymėtina, kad anksčiau yra aptarti tik esminiai ES institucijų teisèto neveikimo atvejai, kuriuos ieškovai nesèkmingai siekia kvestionuoti. Savaime suprantama, kad ir pagal kitus ES teisés aktus ES institucijos gali teisètai neveikti, jeigu tie straipsniai suteikia plačią diskreciją, o ne ịpareigoja veikti. Anksčiau aptarti ES teismų praktikos pavyzdžiai parodo, kad tuo atveju, kai ES teisés norma yra dispozityvi ir nenumato sąlygų, kurioms esant ES institucija turi veikti, ES institucija toje srityje turi plačią diskrecijos teisę ir toks jos neveikimas laikomas teisètu ir pagrịstu. Dèl šios priežasties preliminariai nustačius, kad ES institucijos neveikimo nebus galima pripažinti neteisètu, manytina, kad ieškovai neturètų kelti ir nepagrịstų reikalavimų ES institucijoms. Dèl šios priežasties dar prieš pareiškiant reikalavimus reikia įvertinti, ar ES institucija pagal atitinkamą normą turi plačią diskrecijos teisę.

\section{Neteisètas neveikimas piktnaudžiaujant siaura diskrecijos teise}

Kyla klausimas, ar ES institucijos neveikimas gali būti pripažintas neteisètu, net jeigu ES institucija turi diskrecijos teisę ir neveikia? Profesorius Y. A. Takahashi, tyrinejęs diskrecijos ypatumus Vokietijos teisèje, nurodè, kad pasitaiko atvejų, kai Vokietijos administracinès institucijos neteisètai neveikia ir tuo atveju, kai minètos institucijos nerealizuoja diskrecijos, nors privalo diskreciją realizuoti pagal teisès aktų reikalavimus. Tokia situacija yra laikoma piktnaudžiavimu diskrecija ${ }^{37}$. Teisineje

36 ES Bendrojo Teismo 1996 m. gegužès 22 d. sprendimas byloje AITEC prieš ES Komisiją, bylos Nr. T-277/94, Rink. p. II-00351, paras 25, 27, 28, 66.

37 Takahashi, Y. A. Discretion in German Administrative Law: Doctrinal Discourse Revisited, European Public Law, Volume 6, Issue 1, 2000, p. 69-80. 
literatūroje nèra atskleista, ar ES institucijų neveikimo atveju yra įmanomas piktnaudžiavimas diskrecijos teise. Ar piktnaudžiavimas diskrecijos teise neveikimo atveju imanomas, nèra expressis verbis konstatuota ir ES teismų praktikoje. Nepaisant to, ES institucijų neveikimo atveju piktnaudžiavimas diskrecijos teise yra neabejotinai imanomas reiškinys. Ši situacija nagrinẻjama toliau.

Kaip matyti iš ES teismų praktikos, siekiant pripažinti ES institucijos neveikimą neteisètu, kiekvienu atveju yra būtina nagrinèti, ar ES institucija pagal tam tikrą normą turi diskreciją. Jeigu nustatoma, kad diskrecija egzistuoja, tuomet reikia nustatyti diskrecijos apimtį, t. y. reikia identifikuoti plačią diskreciją (angl. broad discretion) ar siaurą diskreciją (angl. narrow discretion). Jeigu byloje bus nustatyta, kad ES institucija disponuoja plačia diskrecijos teise, neapribota veikimo sąlygomis, tuomet jos neveikimas bus pateisinamas. Tačiau jeigu bus nustatyta, kad ES institucija turi siaurą diskreciją, kuri veikimo sąlygomis yra apribota, jos neveikimas galès būti pripažintas neteisetu, kai ji tos diskrecijos nerealizuos ${ }^{38}$.

Vadovaujantis generalinès advokatės Stix-Hackl išvada bei ES teismų praktika Camar byloje, galima atpažinti siauros diskrecijos sąvoką ir reikšmę ES instituciju neveikimo kontekste. Kaip matyti iš šios išvados ir ES teismų praktikos, ES institucijų neveikimo kontekste siaura diskrecija būna numatoma sąlyginèje ES teisès normo$\mathrm{je}^{39}$. Tai teisès norma, kuri suteikia ES institucijai diskreciją veikti, tačiau kartu nurodo ir sąlygas, kurioms ịvykus, ES institucija privalo realizuoti diskrecijos teisę ir imtis veiksmų. Taigi, atsiradus tokioms sąlygoms, ES institucija negali atsisakyti veikti, ji privalo igyvendinti diskreciją, t. y. veikti ${ }^{40}$. Jeigu ES institucija ịvykus sąlygoms neveikia, ji piktnaudžiauja diskrecijos teise ir toks jos neveikimas gali būti pripažintas neteisètu.

Siauros diskrecijos pavyzdys yra anksčiau galiojusio $1993 \mathrm{~m}$. vasario 13 d. ES Tarybos reglamento (EEB) Nr. 404/93 $3^{41}$ dèl bendro bananų rinkos organizavimo 30 straipsnyje, kuriame įtvirtinta ES Komisijai diskrecijos teisè imtis konkrečių veiksmų. Minètas straipsnis nustate ir tai, kad esant atitinkamoms sąlygoms, ES Komisija tam tikrų veiksmų imtis privalo. Šis reglamentas pakeitė ankstesnius nacionalinius teisès aktus, kurie reguliavo bananų prekybą su trečiosiomis šalimis bei nustatė bananų importo tarifines kvotas iš trečiųjų šalių importuojamiems bananams. Šio reglamento 30 straipsnyje buvo ịtvirtinta, kad jeigu reikès konkrečių priemonių palengvinti perèjimą nuo anksčiau galiojusių priemonių prie šiame reglamente nustatytų priemonių,

38 ES Teisingumo Teismo 2005 m. liepos 12 d. sprendimas byloje ES Komisija prieš CEVA Santé Animale SA ir Pfizer Enterprises Sàrl, bylos Nr. C-198/03 P, Rink. p. I-06357, paras 64-71.

39 ES Bendrojo Teismo 2000 m. birželio 8 d. sprendimas Camar srl and Tico srl prieš ES Komisija, sujungtų bylų Nr. T-79/96, T-260/97 ir T-117/98, Rink. nepaskelbta, para 153.

40 Generalinès advokatès Stix-Hackl išvada byloje ES Komisija prieš Camar Srl ir Tico Srl, bylos Nr. C-312/00 P, Rink. p. I-11355, paras 138-142.

41 Šiuo metu tekste minimas reglamentas Nr. 404/93 yra pakeistas 2006 m. gruodžio 19 d. Tarybos reglamentu (EB) Nr. 2013/2006 dẻl bananų sektoriaus, OJ L 384. 
ES Komisija savo nuožiūra imasi bet kokių laikino pobūdžio priemonių. Ieškovas importuodavo bananus iš Somalio ị Italiją. Prasidejęs Somalio pilietinis karas bei vèliau potvynis apsunkino bananų importą ir ieškovo importuojamas bananų kiekis iš Somalio ėmè mažèti. Ieškovas prašè ES Komisijos, kad ji, vadovaudamasi reglamento Nr. 404/93 30 straipsniu, perskirstytų Somalio tarifinę kvotą kitoms šalims, iš kurių būtų galima importuoti bananus ${ }^{42}$. ES Komisija jokių veiksmų nesièmè, todèl ieškovas kreipèsi į ES Bendrąji Teismą prašydamas tokị ES Komisijos neveikimą pripažinti neteisètu. Ieškovas teigè, kad nepaisant to, kad reglamento 30 straipsnis suteikia diskreciją ES Komisijai veikti, ES Komisija piktnaudžiauja diskrecijos teise, nes atsirado būtinybė ja pasinaudoti ${ }^{43}$. ES Bendrasis Teismas byloje Camar nusprende, kad ES Komisijos neveikimas buvo neteisètas ${ }^{44}$. Minètoje byloje ES Bendrasis Teismas konstatavo, kad ES Komisija pagal reglamento Nr. 404/93 30 straipsnį netinkamai naudojosi diskrecijos teise spręsdama dèl papildomų priemonių priemimo, kurios užtikrintų bananų rinkos veikimą. ES Bendrasis Teismas išanalizavo ir atkreipè dèmesi i tai, kad šio reglamento 30 straipsnis esant poreikiui ${ }^{45}$ ne tik suteikia teisę, bet ir ịpareigoja ES Komisiją imtis atitinkamų veiksmų, todẻl diskrecijos teisė šiuo atveju siaurinama iki pareigos veikti. ES Bendrasis Teismas šioje byloje išaiškino, kad ES institucijos privalo veikti tuo atveju, kai peréjimas prie bendros bananų rinkos ivedant tarifines kvotas gali pažeisti pagrindines prekiautojų bananais teises, tokias, kaip teisè vykdyti profesinę veiklą. Teismas nustatė ES Komisijos neteisètą neveikimą dèl to, kad esant būtinybei pagal minèto reglamento 30 straipsnị, ji nepadidino ieškovui bananų kvotos iš kitų šalių nei Somalio, ir nesuteikè atitinkamų licencijų, t. y. ES Bendrasis Teismas iš esmès konstatavo, kad būtent dèl piktnaudžiavimo siaura diskrecija, kurios ES Komisija nerealizavo pagal minèto reglamento 30 straipsni, ES Komisijos neveikimas yra neteisètas ${ }^{46}$. ES Teisingumo Teismas sprendime byloje $\mathrm{Ca}$ mar patvirtino, kad ES Bendrojo Teismo išvados byloje Camar dèl tokio piktnaudžiavimo diskrecijos teise buvo pagristos ${ }^{47}$.

Atsižvelgdami ị anksčiau išdèstytus argumentus, galime teigti, kad sąlyginę teisès normą su siaura diskrecija galime atpažinti pagal formulę „Jeigu - x, tai - y“. Tai reiš-

42 ES Bendrojo Teismo $2000 \mathrm{~m}$. birželio $8 \mathrm{~d}$. sprendimas sujungtose bylose Camar srl and Tico srl prieš ES Komisiją, bylų Nr. T-79/96, T-260/97 ir T-117/98, Rink. nepaskelbta, paras 20, 23-27.

43 Šio reglamento 30 straipsnio fraze „, „..> savo nuožiūra<...>“ parodo ES Komisijos turimą diskrecijos teisę imtis veiksmų.

44 ES Bendrojo Teismo $2000 \mathrm{~m}$. birželio $8 \mathrm{~d}$. sprendimas sujungtose bylose Camar srl and Tico srl prieš ES Komisija, bylų Nr. T-79/96, T-260/97 ir T-117/98, para 153, Rink. nepaskelbta.

45 Reglamente Nr. 404/93 vartojama ịpareigojanti frazė „Jeigu po $1993 \mathrm{~m}$. liepos mènesio reikès konkrečiu priemoniu palengvinti perëjimą nuo anksčiau galiojusių priemonių <...>“.

46 ES Bendrojo Teismo $2000 \mathrm{~m}$. birželio $8 \mathrm{~d}$. sprendimas sujungtose bylose Camar srl and Tico srl prieš ES Komisiją, bylų Nr. T-79/96, T-260/97 ir T-117/98, para 153.

47 ES Teisingumo Teismo $2002 \mathrm{~m}$. gruodžio $10 \mathrm{~d}$. sprendimas byloje ES Komisiją prieš Camar Srl and Tico, bylos Nr. C-312/00 P, Rink. p. I-11355, para 50. 
kia, kad ịvykus „x“ sąlygai, ES institucija turi realizuoti diskreciją atlikti veiksmus „y“. Todèl siauros diskrecijos įtvirtinimo ar reguliavimo pavyzdys yra ir SESV 66 straipsnis, kuriame itvirtinta, kad „Tais atvejais, kai susidarius išimtinems aplinkybems dèl kapitalo judejimo ị trečiąsias šalis ar iš ju Ekonomines ir pinigu sajungos veikimui kyla arba gali kilti dideliu sunkumu, Taryba, remdamasi Komisijos pasiūlymu ir pasikonsultavusi su Europos centriniu banku, gali trečiuju šaliu atžvilgiu imtis ne ilgiau kaip šešis mènesius taikomu apsaugos priemonių, jei jos būtinai reikalingos". Kaip matyti, ES institucijos pagal SESV 66 straipsnị turi diskreciją veikti, tačiau ši siaura jų diskrecija galètų virsti pareiga, ką parodo SESV 66 straipsnio formuluotè: „jei jos (priemonès - aut. pastaba) taptu būtinai reikalingos". Vadinasi, jeigu esant būtinybei (tam tikroms aplinkybems), ES institucija diskrecijos nerealizuos kaip pareigos, ji piktnaudžiaus diskrecijos teise. ES Teisingumo Teismas byloje Europos Komisija prieš Europos Parlamentą ir ES Tarybq̨ išaiškino, kad ES teisès normoje vartojamas žodis „prireikus“ parodo ES institucijos ịpareigojimą diskrecijos teisę realizuoti kaip pareigą ${ }^{48}$.

Apibendrinant daroma išvada, kad tuo atveju, kai teisės norma nustato ES institucijos kompetenciją, bet kartu nurodo ir sąlygas, kada ta kompetencija privalo būti realizuota, ES institucija, toms sąlygoms atsiradus, negali atsisakyti veikti. Vadinasi, kai ES institucija nerealizuoja siauros diskrecijos ir nesiima veiksmų ỉvykus atitinkamoms sąlygoms, gali būti konstatuojamas ES institucijos piktnaudžiavimas siaura diskrecijos teise. Atsižvelgiant ị tai daroma išvada, kad ieškovo ieškinys dèl neveikimo būtų perspektyvus ir neteisètą neveikimą būtų galima konstatuoti tuo atveju, kai ES institucija piktnaudžiautų siaura diskrecija jos nerealizuodama, nors ịvyktų sąlygos diskrecijos realizavimui.

\section{ES institucijų neteisètas neveikimas esant pareigai veikti}

Pareiga veikti ES teiseje reiškia tai, kad ES institucija turi atlikti konkrečius veiksmus pagal ES teisės aktus ir neturi diskrecijos pasirinkti veikti ar neveikti. Pagal ES teismų praktiką, norint nustatyti, ar kaltinimai ES institucijai dèl jos neteisèto neveikimo yra pagrịsti, reikia patikrinti, ar ES institucija turi pareigą imtis veiksmų (angl. obligation to act, duty to act), ar ES institucija turi tik diskreciją ${ }^{49}$. Jeigu ES institucija turi pareigą veikti (imtis veiksmų), tokiu atveju jos neveikimas gali būti pripažįsta-

48 ES Teisingumo Teismo $2014 \mathrm{~m}$. kovo 18 d. sprendimas byloje ES Komisija prieš Europos Parlamenta ir ES Taryba, bylos Nr. C-427/12, Rink. nepaskelbta, para 51.

49 Žr., pvz., ES Teisingumo Teismo $2014 \mathrm{~m}$. kovo 18 d. sprendimas byloje ES Komisija priě̌ Europos Parlamenta ir ES Tarybą, bylos Nr. C-427/12, Rink. nepaskelbta, para 76, Bendrojo Teismo 2011 m. rugsejo 20 d. sprendimas sujungtose bylose Arch Chemicals ir Arch Timber Protection prieš Komisiją, bylų Nr. T-400/04, T-402/04 ir T-404/04, Rink. nepaskelbta, para 57, 84; Bendrojo Teismo 2011 m. rugsèjo 29 d. sprendimas byloje Ryanair prieš ES Komisiją, bylos Nr. T-442/07. Rink. p. II-00333, paras 27-28. 
mas neteisètu. Pagal mokslininkès M. Forowicz tyrimą, pareigos koncepcija ES teisèje yra artima Prancūzijos administracinès teisès compétence liée doktrinai. Pagal compétence liée doktriną, Prancūzijos administracinè institucija privalo veikti ir neturi dèl to pasirinkimo laisvès ${ }^{50}$. Prancūzijos administracineje teisèje ir teismų praktikoje pripažistama, kad Prancūzijos valdžios institucija pažeidè pareigą veikti, jeigu ji neturèjo diskrecijos teisès pasirinkti veikti ar neveikti, kitaip tariant, turèjo griežtą pareigą veikti ${ }^{51}$. ES Teismai taip pat savo praktikoje yra įtvirtinę, kad ES institucijos veikimas per protingą terminą yra bendrasis ES teisès principas, galiojantis visose srityse, kuriose ES institucijos turi pareigą veikti. Šis principas yra sudètinè ES gero administravimo (angl. sound administration) dalis. Ar šis principas nepažeidinejjamas ir ar ES institucija per ilgai neigyvendina savo pareigos veikti, reikia nustatinèti individualiai kiekvienoje byloje ${ }^{52}$.

Kaip matyti iš ES teismų praktikos, teisès normos imperatyvumas arba dispozityvumas paprastai parodo, ar ES institucija turi pareigą, ar turi diskreciją veikti ${ }^{53}$. Jeigu teisès norma yra imperatyvi ir joje aiškiai formuojama pareiga veikti, ES institucija negali atsisakyti veikti, nes priešingu atveju jos neveikimas galètų būti pripažintas neteisètu. Pavyzdžiui, ES Bendrasis Teismas, nagrinėdamas bylą Pioneer Hi-Bred konstatavo, kad ES Tarybos sprendimo Nr. 1999/468/EB 5(4) straipsnis $^{54}$ formuojamas imperatyviai ir nepalieka ES Komisijai diskrecijos teisès pasirinkti neveikti, todèl ES Komisijos neveikimas buvo pripažintas neteisètu ${ }^{55}$. Pavyzdžiui, SESV 310 straipsnyje yra imperatyviai numatyta, kad „Sajungos metini biudžeta nustato Europos Parlamentas ir Taryba pagal 314 straipsni“. SESV 314(3) straipsnyje taip pat imperatyviai numatyta, kad „Taryba priima savo pozicija dèl biudžeto projekto ir ja perduoda Europos Parlamentui ne veliau kaip iki tu metų, po kuriu tas biudžetas bus vykdomas,

50 Forowicz, M. State discretion as a paradox of EU evolution, 2011 [interaktyvus]. [žiūrèta 2014-07-11]. <http://cadmus.eui.eu/bitstream/handle/1814/18835/MWP_Forowicz_2011_27. pdf? sequence $=1>$, p. 6 .

51 Schwarze, J. European administrative law, revised 1st edition, Sweet\&Maxwell, 2010, p. 264.

52 Žr., pvz., Ibid., para 56, ES Teisingumo Teismo $1973 \mathrm{~m}$. gruodžio $11 \mathrm{~d}$. sprendimas byloje Gebrüder Lorenz GmbH prieš Vokietijos Federacinę Respublika ir Land Rheinland-Pfalz, bylos Nr. 120/73, Rink. p. 01471, para 4, 1987 m. lapkričio 24 d. sprendimas byloje Rijn-ScheldeVerolme (RSV) Machinefabrieken en Scheepswerven NV prieš ES Komisija, bylos Nr. 223/85, Rink. p. 04617, paras 12-17.

53 ES Bendrojo Teismo $1992 \mathrm{~m}$. lapkričio $18 \mathrm{~d}$. sprendimas byloje Rendo NV, Centraal Overijsselse Nutsbedrijven NV and Regionaal Energiebedrijf Salland NV prieš ES Komisiją, bylos Nr. T-16/91, Rink. p. II-02417, paras 96-101.

54 Tarybos 1999 m. birželio 28 d. sprendimo Nr. 1999/468/EB 5(4) straipsnyje numatyta, kad „Kai numatytos priemonés neatitinka komiteto nuomonès arba nuomone nepareiškiama, Komisija nedelsdama pateikia Tarybai pasiūlyma dèl priemoniu, kuriu turi büti imtasi, ir informuoja Europos Parlamenta".

55 ES Bendrojo Teismo 2013 m. rugsejo 26 d. sprendimas byloje Pioneer Hi-Bred International prieš ES Komisiją, bylos Nr. T-164/10, Rink. nepaskelbta, paras 31, 39, 41, 58, 81. 
spalio $1 d$. Taryba išsamiai informuoja Europos Parlamenta apie motyvus, paskatinusius ja priimti savo pozicija". Europos Parlamentas byloje Europos Parlamentas prieš ES Tarybą praše pripažinti ES Tarybos neteisètą neveikimą turint pareigą pagal SESV 314 straipsni veikti dèl to, kad ES Taryba nepateikè Europos Parlamentui biudžeto projekto, nors privalejo tai padaryt $\mathrm{i}^{56}$. ES Teisingumo Teismas šioje byloje konstatavo, kad ES Taryba turejo pareigą veikti pagal minètas imperatyvias normas ${ }^{57}$. Generalinis advokatas Mischo taip pat pažymėjo, kad dèl šios normos imperatyvaus pobūdžio nebuvo jokių abejonių, todèl, nesièmusi veiksmų, ES Taryba neteisètai neveiké ${ }^{58}$.

Svarbu atkreipti demesį, kad ES teismai savo praktikoje nustate taisyklę, kad ES institucija turi pareigą veikti ir tuo atveju, jeigu tik konkreti atitinkama ES institucija tam tikroje srityje turi kompetenciją veikti. Vienas iš anksčiau minètą taisyklę suponuojančių teisinio reguliavimo pavyzdžių yra SESV 101(3) straipsnis, pagal kurị tik ES Komisija turi kompetenciją spręsti, ar suteikti išimtị ir leisti įmonių susitarimus, i̇monių asociacijų sprendimus ir suderintus veiksmus, kurie gali paveikti konkurenciją vidaus rinkoje, tačiau kurie „<...>padeda tobulinti prekiu gamyba ar paskirstymą arba skatinti technikos ar ekonomikos pažangą, kartu sudarydami salygas vartotojams sąžiningai dalytis gaunama nauda <... “". Savaime suprantama, ittvirtinta pareiga pagal SESV 101(3) straipsni nereiškia, kad ES Komisija yra ịpareigota suteikti išimtị, tačiau ji reiškia, kad ES Komisija turi pareigą priimti galutinị sprendimą suteikti ar nesuteikti išimtị, kurị ieškovas galètų ginčyti ES Teisingumo Teisme. Paprastai pagal ES teismų praktiką ES institucijos turi pareigą išnagrinèti ieškovų prašymus ir skundus, tačiau neturi pareigos inicijuoti specialius procesus, tokius kaip, pavyzdžiui, tirti konkurencijos teisès pažeidimus ir nustatyti pažeidimąa ${ }^{59}$. Tokia pati situacija egzistuoja ir valstybès pagalbos srityje. ES Bendrasis Teismas byloje Gestevision nurodé, kad SESV 108(3) straipsnis reglamentuoja specialią procedūrą, pagal kurią tik ES Komisija valstybès narès prašymu gali leisti teikti valstybės pagalbą arba pakeisti jos pobūdį, todèl ši sritis yra ES Komisijos išimtinè kompetencija. Byloje Gestevision buvo nagrinejama situacija, kai Prancūzija neinformavo ES Komisijos apie savo teikiamą pagalbą ir todèl ieškovai kreipèsi ị ES Komisiją, kad ji uždraustų tokią pagalbą teikti. ES Komisija jokių veiksmų nesièmė ir ị ieškovų skundus nereagavo, todèl ieškovai siekè pripažinti tokį neveikimą neteisètu ${ }^{60}$. ES Bendrasis Teismas šioje

56 ES Teisingumo Teismo 1988 m. liepos 12 d. sprendimas byloje Europos Parlamentas prieš ES Taryba, bylos Nr. 377/87, Rink. p. 04017, para 1.

57 Ibid., paras 8-11.

58 Generalinio advokato Mischo 1988 m. gegužès 26 d. išvada sujungtose bylose Europos Parlamentas prieš ES Tarybą, bylų Nr. 377/87 ir 383/87, Rink. p. 04017, para 14.

59 Žr., pvz., ES Bendrojo Teismo 1995 m. sausio 24 d. sprendimas byloje Bureau européen des médias de l’industrie musicale prieš ES Komisiją, bylos Nr. T-114/92, Rink. p. II-00147, para 62.

60 ES Bendrojo Teismo 1998 m. rugsẻjo 15 d. sprendimas byloje Gestevision Telecinco SA prieš ES Komisija, bylos Nr. T-95/96, Rink. p. II-03407, paras 49-52. 
Gestevision byloje konstatavo, kad ES Komisija, kaip vienintelè pagal SESV 108(3) straipsnị kompetentinga institucija imtis veiksmų, privalëjo kruopščiai bei nešališkai išnagrinèti ieškovų skundus, be to, privalèjo nagrinèti visas reikšmingas aplinkybes, net jeigu skunde nebuvo prašoma jas išnagrinèti ${ }^{61}$.

ES Teisingumo Teismas savo praktikoje taip pat konstatavo, kad ES institucijos turi pareigą atsižvelgti ị teismų praktikoje nustatytas taisykles. Pavyzdžiui, ES Teisingumo Teismas byloje Yusef nusprendè, kad ES Komisija, užšaldydama ieškovo lèšas, remdamasi tik nemotyvuotu Jungtinių Tautų Sankcijų komiteto pranešimu spaudai, nesupažindinusi ieškovo su įrodymais ir nereaguodama i ieškovo prašymus panaikinti sankcijas, pažeidè pareigą vadovautis ES Teisingumo Teismo bylose Kadi $I^{62}$ ir Kadi $I I^{63}$ suformuotomis taisyklèmis, nustatančiomis, kad užšaldyti lèšas galima tik turint patikimus ịrodymus ir su jais supažindinus asmenį ${ }^{64} \mathrm{ES}$ teismų praktikoje buvo konstatuota ir tai, kad ES institucijos privalo vykdyti ES teismų sprendimus. Tokio konstatavimo pagrindas - SESV 266 straipsnis, kuriame itvirtinta, kad „Institucija, istaiga ar organas, kurio aktas buvo paskelbtas negaliojančiu arba kurio neveikimas pripažintas prieštaraujančiu šiai Sutarčiai, privalo imtis būtinu priemoniu Europos Sajungos Teisingumo Teismo sprendimui juvkkdyti“. Detalizuojant minimą situaciją pažymėtina, kad ES Bendrasis Teismas byloje Alfastar prieš ES Tarybą I prièmė sprendimą, kuriuo panaikino $2008 \mathrm{~m}$. gruodžio $1 \mathrm{~d}$. ES Tarybos nutarimą atmesti ieškovo pasiūlymą viešojo pirkimo konkurse ${ }^{65}$. ES Taryba nesièmé jokių veiksmų teismo sprendimui ịvykdyti, todèl ieškovas inicijavo naują bylą teisme ir prašè teismo pripažinti, kad ES Taryba pažeidè pareigą veikti pagal SESV 266 straipsnị ịvykdyti teismo sprendimą. Pagal naują ieškinį dèl neveikimo Bendrasis Teismas byloje $\mathrm{Al}$ fastar prieš ES Tarybą II pripažino, kad SESV 266 straipsnis yra imperatyvaus pobūdžio ir ịpareigoja bet kurią ES instituciją, kurios atžvilgiu yra priimtas sprendimas, to sprendimo laikytis ir užtikrinti jo ịgyvendinimą ${ }^{66}$. Atkreipiamas dèmesys ị tai, kad

61 Ibid., para 53; taip pat žr. ES Teisingumo Teismo $1998 \mathrm{~m}$. balandžio 2 d. sprendimą byloje ES Komisija prieš Chambre Syndicale Nationale des Entreprises de Transport de Fonds et Valeurs (Sytraval) ir Brink's France SARL, bylos Nr. C-367/95 P, Rink. p. I-01719, para 62.

62 ES Teisingumo Teismo $2008 \mathrm{~m}$. rugsèjo $3 \mathrm{~d}$. sprendimas sujungtose bylose Yassin Abdullah Kadi ir kt. prieš ES Tarybą ir ES Komisiją, sujungtų bylų Nr. C-402/05 P ir C-415/05, Rink. p. I-06351, paras 349-349.

63 ES Teisingumo Teismo $2013 \mathrm{~m}$. liepos $18 \mathrm{~d}$. sprendimas byloje ES Komisija ir kt. prieš Yassin Abdullah Kadi, sujungtų bylų Nr. C-584/10 P, C-593/10 P ir C-595/10 P, Rink. nepaskelbta, paras 114-116.

64 ES Bendrojo Teismo 2014 m. kovo 21 d. sprendimas byloje Hani El Sayyed Elsebai Yusef prieš ES Komisija, bylos T-306/10, Rink. nepaskelbta, paras 94-102.

65 ES Bendrojo Teismo 2011 m. spalio 20 d. sprendimas byloje Alfastar Benelux SA prieš ES Taryba, bylos Nr. T57/09, Rink. p. II-00368, para 43.

66 ES Bendrojo Teismo 2013 m. sausio 7 d. sprendimas byloje Alfastar Benelux SA prieš ES Tarybą, Rink. nepaskelbta, bylos Nr. T-274/12, Rink. nepaskelbta, paras 16-18. 
ES Taryba šioje byloje apskritai neginčijo aplinkybès, kad ji turi pareigą veikti pagal SESV 266 straipsnio normas. Savaime suprantama, kad protingumo, teisingumo, sąžiningumo principai reikalauja laikytis teismų sprendimuose nurodytų ịpareigojimų. Šis faktas toks akivaizdus, kad ES Taryba nelaukė aiškiai jai nepalankios bylos baigties ir teismo sprendimą ịvykdè. Kita vertus, situacija, kai teismų sprendimai nevykdomi, netoleruotina teisiniu aspektu, todèl ES institucija pareigą pagal SESV 266 straipsni privalètų igyvendinti nedelsdama po to, kai tik jos atžvilgiu yra priimamas nepalankus sprendimas.

Apibendrinant galima teigti, kad ES teisès normos imperatyvumas suponuoja ES institucijos pareigą veikti, o ES institucijos neveikimas, esant imperatyviai pareigai veikti, galètų būti pripažistamas neteisètu. Turèdama pareigą, bet neturinti diskrecijos teisès neveikti, ES institucija negali atsisakyti veikti. Dėl šios priežasties ieškiniai dèl ES institucijų neveikimo, kai ES institucija neveikia turèdama pareigą veikti, yra perspektyvūs, be to, tokio neveikimo ginčijimas užtikrintų, kad ES institucijos tinkamai vykdytų savo pareigas ir nepažeistų iš ES teisès joms kylančių îpareigojimų.

\section{Išvados}

ES teisèje sąvoka „neveikimas“ tradiciniu požiūriu turètų būti suprantama kaip teisès akto neprièmimas imtis veiksmų ir toks neveikimas turètų būti ginčijamas pagal SESV 265 straipsnį. Remiantis alternatyviu požiūriu, „neveikimas“ turètų būti suprantamas ir kaip negatyvaus teisės akto priemimas, kuriuo atsisakoma atlikti veiksmus. Toks negatyvus teisès aktas turètų būti ginčijamas pagal SESV 263 straipsnị.

ES teismų praktikoje pripažįstama, kad ES institucija teisètai neveikia tada, kai ji turi plačią diskrecijos teisę veiksmų nesiimti. Tokia plati diskrecijos teisè identifikuojama ES teisès akto normose ir ji ES institucijai suteikia tik kompetenciją veikti, tačiau nenurodo sąlygų, kurioms esant ES institucija privalo diskreciją realizuoti.

Siaura diskrecija nustatoma sąlygineje ES teisès normoje, kai ta norma ne tik suteikia diskreciją, bet ir numato sąlygas, kurioms esant ES institucija privalo veikti, t. y. realizuoti diskreciją. Piktnaudžiavimo siaura diskrecija atveju ES institucijos neveikimas gali būti pripažįstamas neteisètu.

Imperatyvaus pobūdžio ES teisès normose nustatoma ES institucijos pareiga veikti, nepaliekant ES institucijai diskrecijos teisės nesiimti veiksmų, t. y. neveikti. Kai ES institucija nevykdo pareigu pagal imperatyvias ES teisès normas, paprastai konstatuojamas ES institucijų neteisètas neveikimas.

Ginčijant ES institucijų neveikimą, palankaus ieškovui sprendimo galima tikètis tik tuo atveju, kai kreipiamasi dèl neteisèto ES institucijos neveikimo, t. y. kai kreipiamasi dèl neveikimo piktnaudžiaujant siaura diskrecijos teise ar neveikimo turint pareigą veikti. Dèl šios priežasties, dar prieš pareiškiant ieškinị dèl neveikimo, rekomenduotina pačiam ieškovui preliminariai įvertinti ES institucijos neveikimo teisètumą. 


\section{Literatūra}

Biber, E. Two Sides of the Same Coin: Judicial Review of Administrative Agency Action and Inaction. Virginia Environmental Law Journal. 2008. Vol. 26, No.: 461-503.

Craig, P.; de Búrca, G. EU Law. Text, cases and materials", fifth edition, Oxford University press, 2011.

ES Tarybos 2006 m. gruodžio 19 d. reglamentas (EB) Nr. 2013/2006 dèl bananų sektoriaus, OL L 384.

ES Tarybos 2002 m. gruodžio 16 d. reglamentas (EB) Nr. 1/2003 dèl konkurencijos taisyklių, nustatytų Sutarties 81 ir 82 straipsniuose, OL L 1.

ES Tarybos $1993 \mathrm{~m}$. vasario $13 \mathrm{~d}$. reglamentas (EEB) Nr. 404/93 dèl bendro bananų rinkos organizavimo, OL L 047.

ES Teisingumo Teismo $2014 \mathrm{~m}$. kovo 18 d. sprendimas byloje Europos Komisija prieš Europos Parlamenta ir ES Tarybą, bylos Nr. C-427/12, Rink. nepaskelbta.

ES Teisingumo Teismo 2013 m. lapkričio 19 d. sprendimas byloje ES Komisija prieš ES Taryba, bylos Nr. C-63/12, Rink. nepaskelbta.

ES Teisingumo Teismo 2013 m. liepos $27 \mathrm{~d}$. sprendimas byloje Alexandru Octavian Concal prieš ES Komisija, bylos Nr. C-570/12 P, Rink. nepaskelbta.

ES Teisingumo Teismo $2013 \mathrm{~m}$. liepos 27 d. sprendimas byloje Emil Micsunescu prieš ES Komisija, bylos Nr. C-569/12 P, Rink. nepaskelbta.

ES Teisingumo Teismo $2013 \mathrm{~m}$. liepos 18 d. sprendimas byloje ES Komisija ir kt. prieš Yassin Abdullah Kadi, sujungtu bylų Nr. C-584/10 P, C-593/10 P ir C-595/10 P, Rink. nepaskelbta.
ES Teisingumo Teismo $2013 \mathrm{~m}$. liepos 18 d. sprendimas byloje Dow, bylos Nr. C-499/11 P, Rink. nepaskelbta.

ES Teisingumo Teismo $2013 \mathrm{~m}$. birželio 27 d. sprendimas byloje Doru Cristian Ioanovici prieš ES Komisiją, bylos Nr. C-568/12 P, Rink. nepaskelbta.

ES Teisingumo Teismo $2013 \mathrm{~m}$. gegužès 16 d. sprendimas byloje ES Komisija prieš Ryanair Ltd, bylos Nr. C-615/11 P, Rink. nepaskelbta.

ES Teisingumo Teismo 2010 m. lapkričio 18 d. sprendimas byloje NDSHT prieš ES Komisija, bylos Nr. C-322/09 P, Rink. p. I-11911.

ES Teisingumo Teismo $2008 \mathrm{~m}$. rugsèjo $3 \mathrm{~d}$. sprendimas sujungtose bylose Yassin Abdullah Kadi ir kt. prieš ES Taryba ir ES Komisiją, sujungtų bylų Nr. C-402/05 P ir C-415/05, Rink. p. I-06351.

ES Teisingumo Teismo $2005 \mathrm{~m}$. liepos 12 d. sprendimas byloje ES Komisija prieš CEVA Santé Animale SA ir Pfizer Enterprises Sàrl, bylos Nr. C-198/03 P, Rink. p. I-06357.

ES Teisingumo Teismo $2003 \mathrm{~m}$. sausio 9 d. sprendimas byloje Petrotub SA ir Republica SA prieš Europos Sajungos Tarybą, bylos Nr. C-76/00 P., Rink. p. I-00079.

ES Teisingumo Teismo $2003 \mathrm{~m}$. rugsejjo 30 d. sprendimas byloje Comité des industries $d u$ coton et des fibres connexes de l'Union européenne (Eurocoton) ir kt. prieš Europos Sajungos Taryba, bylos Nr. C-76/01P, Rink. p. I-10091.

ES Teisingumo Teismo $2002 \mathrm{~m}$. gruodžio 10 d. sprendimas byloje ES Ko- 
misija prieš Camar Srl and Tico, bylos Nr. C-312/00 P, Rink. p. I-11355.

ES Teisingumo Teismo 1999 m. lapkričio 18 d. sprendimas Pharos SA prieš ES Komisija, bylos Nr. C-151/98 P, Rink. p. I-08157.

ES Teisingumo Teismo 1999 m. spalio 5 d. sprendimas byloje Christos Apostolidis ir kt. prieš ES Komisija, bylos Nr. C-327/97 P, Rink. p. I-06709.

ES Teisingumo Teismo $1996 \mathrm{~m}$. liepos 30 d. sprendimas byloje Bosphorus Hava Yollari Turizm ve Ticaret AS prieš Minister for Transport, Energy and Communications ir kt., bylos Nr. C-84/95, Rink. p. I-03953.

ES Teisingumo Teismo 1995 m. lapkričio 13 d. sprendimas byloje Dumez prieš ES Komisija, bylos Nr. T-126/95, Rink. p. II-02863.

ES Teisingumo Teismo $1993 \mathrm{~m}$. gruodžio 14 d. sprendimas Antonio Calvo Alonso-Cortès prieš ES Komisiją, bylos Nr. T-29/93, Rink. p. II-01389.

ES Teisingumo Teismo $1993 \mathrm{~m}$. vasario 16 d. sprendimas byloje Empresa Nacional de Urânio SA prieš ES Komisija, bylos Nr. C-107/91, Rink. p. I-00599.

ES Teisingumo Teismo $1991 \mathrm{~m}$. lapkričio 21 d. sprendimas byloje Fédération nationale $d u$ commerce extérieur des produits alimentaires ir Syndicat prieš Prancūzijos Respubliką, bylos Nr. C-354/90, Rink. p. I-05505.

ES Teisingumo Teismo $1990 \mathrm{~m}$. birželio 26 d. sprendimas byloje Zardi, bylos Nr. C-8/89, Rink. p. I-2515.

ES Teisingumo Teismo $1990 \mathrm{~m}$. vasario 21 d. sprendimas sujungtose bylose Wuidart ir kt., bylų Nr. C-267/88 ir C-285/88, Rink. p. I-435.

ES Teisingumo Teismo $1990 \mathrm{~m}$. vasario 14 d. sprendimas byloje Prancūzija prieš ES Komisija, bylos Nr. C-301/87, Rink. p. I-00307.

ES Teisingumo Teismo $1988 \mathrm{~m}$. rugsèjo 27 d. sprendimas byloje Europos Parlamentas prieš ES Taryba, bylos Nr. 302/87, Rink. p. 05615.

ES Teisingumo Teismo $1988 \mathrm{~m}$. liepos 12 d. sprendimas byloje Europos Parlamentas prieš ES Taryba, bylos Nr. 377/87, Rink. p. 04017.

ES Teisingumo Teismo 1987 m. lapkričio 24 d. sprendimas byloje Rijn-ScheldeVerolme (RSV) Machinefabrieken en Scheepswerven NV prieš ES Komisija, bylos Nr. 223/85, Rink. p. 04617.

ES Teisingumo Teismo $1985 \mathrm{~m}$. gegužès 22 d. sprendimas byloje Europos Parlamentas prieš ES Tarybą, bylos Nr. 13/83, Rink. p. 01513.

ES Teisingumo Teismo $1984 \mathrm{~m}$. vasario 21 d. sprendimas byloje St. Nikolaus Brennerei und Likörfabrik, Gustav Kniepf-Melde GmbH prieš Hauptzollamt Krefeld, bylos Nr. 337/82, Rink. p. 01051.

ES Teisingumo Teismo $1977 \mathrm{~m}$. kovo 22 d. sprendimas byloje Steinike \& Weinlig prieš Vokietijos Federacinę Respublika, bylos Nr. C-78/76, Rink. p. 00595.

ES Teisingumo Teismo 1973 m. gruodžio 11 d. sprendimas byloje Gebrüder Lorenz GmbH prieš Vokietijos Federacinę Respublikg ir Land Rheinland-Pfalz, bylos Nr. 120/73, Rink. p. 01471.

ES Teisingumo Teismo $1971 \mathrm{~m}$. liepos 13 d. sprendimas byloje Deutscher Komponistenverband prieš ES Komisija, bylos Nr. 8/71, Rink. nepaskelbta.

ES Teisingumo Teismo $1966 \mathrm{~m}$. kovo 1 d. sprendimas byloje Alfons Lütticke $\mathrm{GmbH}$ prieš ES Komisija, bylos Nr. 48/65, Rink. p. 00019. 
ES Bendrojo Teismo $2014 \mathrm{~m}$. kovo $21 \mathrm{~d}$. sprendimas byloje Hani El Sayyed Elsebai Yusef prieš ES Komisija, bylos T-306/10, Rink. nepaskelbta.

ES Bendrojo Teismo $2013 \mathrm{~m}$. gruodžio 5 d. nutartis byloje $\mathrm{MeD}$ Concilia $\mathrm{Srl}$ prieš ES Taryba ir ES Komisija, bylos Nr. T-574/13, Rink. nepaskelbta.

ES Bendrojo Teismo 2013 m. gruodžio $5 \mathrm{~d}$. nutartis byloje Adr Tiber Srl prieš ES Taryba ir ES Komisija, bylos Nr. T-573/13, Rink. nepaskelbta.

ES Bendrojo Teismo 2013 m. gruodžio 5 d. nutartis byloje MAG Dispute Resolution Srl prieš ES Taryba ir ES Komisija, bylos Nr. T-572/13, Rink. nepaskelbta.

ES Bendrojo Teismo 2013 m. lapkričio 28 d. sprendimas byloje $A D R$ Conciliando e ADR C\&M Consulting Srl prieš ES Taryba ir ES Komisiją, bylos Nr. T-475/13, Rink. nepaskelbta.

ES Bendrojo Teismo 2013 m. lapkričio 28 d. sprendimas byloje ADUGI Onlus prieš ES Taryba ir ES Komisija, bylos Nr. T-474/13, Rink. nepaskelbta.

ES Bendrojo Teismo $2013 \mathrm{~m}$. rugsèjo 26 d. sprendimas byloje Pioneer $\mathrm{Hi}$ Bred International prieš ES Komisiją, bylos Nr. T-164/10, Rink. nepaskelbta.

ES Bendrojo Teismo 2013 m. sausio $7 \mathrm{~d}$. sprendimas byloje Alfastar Benelux SA prieš ES Tarybą, bylos Nr. T-274/12, Rink. nepaskelbta.

ES Bendrojo Teismo $2012 \mathrm{~m}$. rugsèjo 25 d. sprendimas byloje Alexandru Octavian Concal prieš ES Komisiją, bylos Nr. T-320/12, Rink. nepaskelbta.

ES Bendrojo Teismo $2012 \mathrm{~m}$. rugsejjo 25 d. sprendimas byloje Emil Micsunescu prieš ES Komisija, bylos Nr. T-314/12, Rink. nepaskelbta.

ES Bendrojo Teismo $2011 \mathrm{~m}$. spalio $20 \mathrm{~d}$. sprendimas byloje Alfastar Benelux
SA prieš ES Taryba, bylos Nr. T-57/09, Rink. p. II-00368.

ES Bendrojo Teismo $2011 \mathrm{~m}$. rugsejjo 29 d. sprendimas byloje Ryanair prieš Komisija, bylos Nr. T-442/07. Rink. p. II-00333.

ES Bendrojo Teismo $2011 \mathrm{~m}$. rugsejo 20 d. sprendimas sujungtose bylose Arch Chemicals ir Arch Timber Protection prieš ES Komisiją, bylų Nr. T-400/04, T-402/04 ir T-404/04, Rink. nepaskelbta.

ES Bendrojo teismo $2011 \mathrm{~m}$. rugsejo 6 d. sprendimas byloje Muhamad Mugraby prieš ES Tarybą ir ES Komisija, bylos Nr. T-292/09, Rink. nepaskelbta.

ES Bendrojo Teismo $2000 \mathrm{~m}$. gruodžio 13 d. sprendimas byloje Services pour le groupement d'acquisitions SARL prieš ES Komisiją, bylos Nr. C-39/00 P, Rink. p. I-11201.

ES Bendrojo teismo $2000 \mathrm{~m}$. birželio 8 d. sprendimas Camar srl and Tico srl prieš ES Komisiją, sujungtų bylų Nr. T-79/96, T-260/97 ir T-117/98, Rink. nepaskelbta.

ES Bendrojo Teismo $1998 \mathrm{~m}$. rugsejjo 15 d. sprendimas byloje Gestevision Telecinco SA prieš ES Komisija, bylos Nr. T-95/96, Rink. p. II-03407.

ES Teisingumo Teismo 1998 m. balandžio 2 d. sprendimą byloje ES Komisija prieš Chambre Syndicale Nationale des Entreprises de Transport de Fonds et Valeurs (Sytraval) ir Brink's France SARL, bylos Nr. C-367/95 P, Rink. p. I-01719.

ES Bendrojo Teismo $1997 \mathrm{~m}$. rugsèjo 29 d. sprendimas byloje Société Anonyme de Traverses en Béton Armé (Sateba), bylos Nr. T-83/97, Rink. p. II-01523. 
ES Bendrojo Teismo $1997 \mathrm{~m}$. liepos 10 d. sprendimas byloje Nr. T-81/96 Christos Apostolidis ir kt. prieš ES Komisija, bylos Nr. T-81/96, Rink. p. FPII-00607.

ES Bendrojo teismo 1996 m. birželio 5 d. sprendimas NMB Prancūzija ir kt. prieš Komisija, bylos Nr. T-162/94, Rink. p. II-427.

ES Bendrojo teismo 1996 m. gegužès 22 d. sprendimas byloje Associazione Italiana Tecnico Economica del Cemento (AITEC) prieš ES Komisiją, bylos Nr. T-277/94, Rink. p. II-00351.

ES Bendrojo Teismo $1995 \mathrm{~m}$. sausio 24 d. sprendimas byloje Bureau européen des médias de l'industrie musicale prieš ES Komisija, bylos Nr. T-114/92, Rink. p. II-00147.

ES Bendrojo teismo 1995 m. sausio $23 \mathrm{~d}$. sprendimas byloje Bundesverband der Bilanzbuchhalter e.V. ES Komisija, bylos Nr. T-84/94, Rink. p. II-00101.

ES Bendrojo teismo sprendimas $1994 \mathrm{~m}$. spalio $27 \mathrm{~d}$. sprendimas byloje Ladbroke Racing Ltd ES Komisija, bylos Nr. T-32/93, Rink. p. II-01015.

ES Bendrojo Teismo $1994 \mathrm{~m}$. liepos 4 d. sprendimas byloje Century Oils Hellas AE prieš ES Komisija, bylos Nr. T-13/94, Rink. p. II-00431 ir kt.

ES Bendrojo Teismo 1994 m. gegužès 27 d. sprendimas byloje J prieš ES Komisija, bylos Nr. T-5/94, Rink. p. II00391.

ES Bendrojo teismo 1992 m. lapkričio 18 d. sprendimas byloje Rendo $N V$, Centraal Overijsselse Nutsbedrijven $N V$ and Regionaal Energiebedrijf Salland NV prieš ES Komisija, bylos Nr. T-16/91, Rink. p. II-02417.

ES Bendrojo teismo 1992 m. lapkričio 11 d. sprendimas byloje Rendo $N V$,
Centraal Overijsselse Nutsbedrijven $N V$ and Regionaal Energiebedrijf Salland NV prieš ES Komisiją, bylos Nr. T-16/91, Rink. p. II-02417.

ES Teisingumo Teismo $1989 \mathrm{~m}$. vasario 14 d. sprendimas byloje Star Fruit Company SA prieš ES Komisiją, bylos Nr. 247/87, Rink. p. 00291.

Forowicz, M. State discretion as a paradox of EU evolution, 2011 [interaktyvus]. [žiūrèta 2014-07-11]. <http://cadmus.eui.eu/bitstream/ handle/1814/18835/MWP_Forowicz_ 2011_27.pdf?sequence $=1>$.

Fritzsche, A. Discretion, scope of judicial review and institutional balance in European Union. Common Market Law Review. 2010. Vol. 47, Iss. 2.

Galligan, D. J. Discretionary powers, a legal study of official discretion. Oxford: Clarendon Press, 1986.

Generalinio advokato Léger $2005 \mathrm{~m}$. vasario 17 d. išvada byloje Rica Foods (Free Zone) NV prieš ES Komisiją, bylos Nr. C-40-03, Rink. p. I-6811.

Generalinès advokatès Stix-Hackl $2002 \mathrm{~m}$. balanžio 16 d. išvada byloje ES Komisija prieš Camar Srl ir Tico Srl, bylos Nr. C-312/00 P, Rink. p. I-11355.

Generalinio advokato Jacobs $1989 \mathrm{~m}$. spalio 4 d. išvada byloje Prancūzija prieš ES Komisija, bylos Nr. C-301/87, Rink. p. I-00307.

Generalinio advokato Mischo $1988 \mathrm{~m}$. gegužès $26 \mathrm{~d}$. išvada sujungtose bylose Europos Parlamentas prieš ES Tarybq, bylų Nr. 377/87 ir 383/87, Rink. p. 04017, para 14 .

Generalinio advokato Capotorti 1979 m. liepos $11 \mathrm{~d}$. išvada byloje GEMA prieš

ES Komisija, bylos Nr. 125/78, Rink. p. 03173. 
Hartley, T. The foundations of European Union law, 8th edition. Oxford University Press, 2014.

Hartley, T. the foundations of the European Community law, 6th edition, Oxford University Press, 2007.

Lenaerts, K.; Maselis, I.; Gutman, K. EU procedural law. Oxford University Press, 2014.

Sutarties dèl Europos Sąjungos veikimo suvestinè redakcija, $2008 \mathrm{~m}$. gegužès 9 d. OL C 115/47.

Schermers, G. H.; Waelbroeck, F. D. Judicial Protection in the European
Union, 6th edition. Kluwer Law International, 2001.

Schwarze, J. European administrative law, revised 1 st edition. Sweet\&Maxwell, 2010.

Simon, D. Le système juridique communautaire. $2^{\text {nd }}$ edition. Paris: Presses Universitaires de France, 1998, Nr. 379.

Steiner, J.; Woods L.; Watson, P. EU law, 11th edition, Oxford University Press, 2012.

Takahashi, Y. A. Discretion in German Administrative Law: Doctrinal Discourse Revisited, European Public Law. 2000. Volume 6, Issue 1.

Anotacija. Analizuojant ES Teisingumo Teismo ir ES Bendrojo Teismo praktika pastebima, kad ieškovai, teikdami ieškinius dèl ES institucijų neveikimo pagal SESV 265 straipsnio nuostatas, neretai siekia kvestionuoti ir toki ES instituciju neveikima, kuris paprastai laikomas pagristu ir teisètu. Šiame straipsnyje atskleidžiama, kokiais kriterijais vadovaujantis yra sprendžiama, ar ES institucijos neveikimas yra teisètas, ar neteisètas, pateikiant teisminès praktikos šioje srityje analizę.

Reikšminiai žodžiai: ES institucijos, ieškiniai dèl neveikimo, SESV 265 straipsnis, neveikimas, diskrecija, pareiga.

\title{
LEGAL AND ILLEGAL INACTION OF EUROPEAN UNION INSTITUTIONS
}

\author{
Arvydas Budnikas
}

Mykolas Romeris University, Lithuania

Summary. Actions for failure to act against European Union (hereinafter also referred to as EU) institutions are governed by Article 265 of the Treaty on the Functioning of the European Union (hereinafter referred to as TFEU). These actions can be successfully brought before the EU courts only in cases where there is illegal inaction on the part of EU institutions. In legal doctrine and EU courts case law, the nature and scope of illegal inaction is not revealed comprehensively. This legal gap causes some serious difficulties for complainants and defending institutions. As it is apparent from the EU courts case law, complainants try to declare reasonable inaction as illegal 
before the EU courts. In some circumstances, there is no possibility to declare inaction as illegal, notwithstanding complainants are trying to do so and supersede the case law of the EU courts. In such cases, defending EU institutions also incur unnecessary expenses and time losses. The aim of this article is to disclose necessary criteria to assess whether inaction is illegal and provide a significant case law in this area. The article is composed of four constituent parts. Firstly, the concept of inaction is defined. Secondly, it is analyzed what inaction is legal and therefore cannot be declared as illegal before the EU courts. Thirdly, in the third and fourth parts, illegal inaction is being identified.

Inaction occurs when EU institution fails to adopt a decision or decides not to take action. However, not every inactivity is considered unlawful. EU case law confirms that discretion and obligation are two concepts which help to distinguish legal and illegal inaction. Inaction is lawful if the EU institution has wide discretion to choose whether to act and such discretion is not limited to acting conditions. The scope of discretion is identified from the EU law. Dispositive EU law without certain conditions to act shows that the EU institution has a wide discretion to choose whether to act or not. Discretion is usually identified from the word "may". However, when the EU institution has a narrow discretion which can be identified from conditional EU law, it is obliged to use that discretion and such failure to act can be considered as unlawful. Illegal inaction is usually declared when EU institutions have no discretion but are obliged by imperative EU law to act. Conclusions can be drawn that when the EU institution has a wide discretion to choose whether to act or not, its inaction cannot be declared illegal. However, if the EU institution has a narrow discretion or obligation to act, its failure to act can be declared as unlawful.

Keywords: EU institutions, actions for failure to act, TFEU Article 265, inaction, discretion, obligation.

Arvydas Budnikas, Mykolo Romerio universiteto Tarptautinès ir Europos Sąungos teisès instituto socialinių mokslų (teisès) doktorantas. Mokslinių tyrimų kryptis: Europos Sąjungos teisè.

Arvydas Budnikas, Mykolas Romeris University, International and European Union Law Institute, PhD student of Social Sciences (Law). Research interest: European Union Law. 